\title{
From introduced species to invader: what determines variation in the success of Codium fragile ssp. tomentosoides (Chlorophyta) in the North Atlantic Ocean?
}

\author{
Annelise Sabine Chapman *,* \\ Institute of Marine Sciences, University of Portsmouth, Ferry Rd., Eastney, \\ Portsmouth PO4 9LY, UK
}

\begin{abstract}
The green alga Codium fragile ssp. tomentosoides (Chlorophyta) has been introduced accidentally and successfully from Japan to many shores of the northern and southern hemispheres, including those of the Northeast and Northwest Atlantic Ocean. On most European coasts, Codium occurs regularly but at low abundances in the intertidal zone and is absent from subtidal habitats. In contrast. Codium is extremely abundant in subtidal kelp beds in the Northwest Atlantic Ocean where it often reaches nuisance proportions. This differential success cannot be accounted for by either the propertics of the invader or by physico-chemical differences between invaded coasts. A theoretical comparison between two regions on opposite sides of the Atlantic Ocean, i.e. Eastern Nova Scotia, Canada, and south central Britain, illustrates how the resident benthic community may determine the difference in relative abundance of Codium in subtidal habitats between northeast America and Europe. In this review, Iow floral species diversity, biological disturbance and facilitation by a previous species invasion are suggested as potential factors for the establishment, success and abundance of Codium in the Northwest Atlantic Ocean, but these require testing in field experiments.
\end{abstract}

\section{INTRODUCTION}

Studies of the ecology of species introductions into novel marine environments have often emphasized (1) the properties of successfully invading species, (2) the characteristics of frequently invaded communities or (3) the transport vectors involved in overcoming barriers of space, climate or habitat (e.g. Carlton \& Geller, 1993; Carlton, 1996; Vermeij, 1996). A successful invasion has been defined as 'the arrival, establishment, and subsequent diffusion of species in a community in which they did not previously exist in historical time' (Carlton, 1989) and similarly as 'the geographical expansion of a species into an area not previously occupied by that species' (Vermeij, 1996). Vermeij (1996) differentiates between three successive stages of invasion, i.e. arrival, establish-

\footnotetext{
- Formerly: A. S. Albrecht

- Present address of A. S. Chapman: University of Plymouth, Department of Biological Sciences, Drake Circus, Plymouth PL4 8AA, UK

(O Biologische Anstalt Helgoland, Hamburg
} 
Table 1. Properties of potentially successful biological invaders according to Lodge (1993) and their applicability to Codium fragile (ssp. tomentosoides)

\begin{tabular}{|c|c|c|c|}
\hline $\begin{array}{l}\text { Properties of } \\
\text { successful invaders } \\
\text { (Lodge, 1993) }\end{array}$ & $\begin{array}{c}\text { Applicability to Codium fragile } \\
\text { (ssp. tomentosoides) }\end{array}$ & & References \\
\hline R-selected traits & $\begin{array}{l}\text { Probably high reproductive output, } \\
\text { high growth rates under favourable } \\
\text { conditions, no true ruderal species } \\
\text { but stress tolerator or competitor }\end{array}$ & $? \pm$ & $\begin{array}{l}\text { Ramus, 1978; Ramus \& } \\
\text { Venable, } 1987\end{array}$ \\
\hline High dispersal rate & $\begin{array}{l}\text { Several dispersal mechanisms: } \\
\text { (1) gametes, (2) adults, ( } 3 \text { ) frag- } \\
\text { ments of adults }\end{array}$ & $? \pm$ & $\begin{array}{l}\text { Fralick \& Mathieson, } \\
\text { 1972; Dromgoole, 1982; } \\
\text { Burrows, } 1991\end{array}$ \\
\hline $\begin{array}{l}\text { Single parent } \\
\text { reproduction }\end{array}$ & Parthenogenesis of female gametes & + & $\begin{array}{l}\text { Churchill \& Moeller, } \\
\text { 1972; Fralick \& Mathie- } \\
\text { son, 1973; Hanisak, } \\
\text { 1979; Burrows, } 1991\end{array}$ \\
\hline $\begin{array}{l}\text { Negative } \\
\text { reproduction }\end{array}$ & $\begin{array}{l}\text { Regrowth from (1) adults, }(2) \text { frag- } \\
\text { ments and (3) individual utricles }\end{array}$ & + & $\begin{array}{l}\text { Fralick \& Mathieson, } \\
\text { 1972; Ramus, } 1972\end{array}$ \\
\hline $\begin{array}{l}\text { High genetic } \\
\text { variability }\end{array}$ & $\begin{array}{l}\text { High intrageneric morphological and } \\
\text { genetic diversity; high intraspecific } \\
\text { diversity (seven) subspecies of } \\
\text { Codium fragile worldwide) }\end{array}$ & + & $\begin{array}{l}\text { Trowbridge, } 1995 \text {, and } \\
\text { references therein; } \\
\text { Silva, personal com- } \\
\text { munication }\end{array}$ \\
\hline Phenotypic plasticity & $\begin{array}{l}\text { Different morphologies between } \\
\text { geographic regions }\end{array}$ & + & $\begin{array}{l}\text { Burrows, } 1991 \\
\text { Silva, } 1992\end{array}$ \\
\hline Large native range & Pacific and Subantarctic Oceans & + & Silva, 1955 \\
\hline Eurytopy & $\begin{array}{l}\text { Intertidal and sublittoral habitats; } \\
\text { exposed and protected shores }\end{array}$ & + & $\begin{array}{l}\text { Silva, 1955; Carlton \& } \\
\text { Scanlon, 1985; } \\
\text { Burrows, 1991; } \\
\text { Trowbridge, } 1995\end{array}$ \\
\hline Polyphagy & $\begin{array}{l}\text { Capability of utilizing various } \\
\text { nitrogen sources (nitrate, nitrite, } \\
\text { ammonium, urea) }\end{array}$ & + & Hanisak, 1979 \\
\hline $\begin{array}{l}\text { Human } \\
\text { commensalism }\end{array}$ & Not applicable & & \\
\hline
\end{tabular}

ment and integration, of which the latter includes ecological links with other species, as well as evolution in the recipient communities.

These definitions cover a wide range of 'success' and integration of a biological newcomer, i.e. they include species which are rare or moderately abundant in the new environment, as well as species which become pests by spreading at high rates and developing into large populations. Few species introductions have a strong impact on the recipient communities, either because the newcomers are not abundant or because they are very small and inconspicuous. The term 'invader' may allow us to discriminate between introduced species beyond their successful establishment: I suggest it be applied to species which through large biomass and abundance, or through strong interactions with natives, significantly alter the structure and composition of the existing community. 
Table 2. Codium fragile ssp. tomentosoides in the Northwest versus the Northeast Atlantic Ocean. Comparison of (1) invasion characteristics, (2) abiotic conditions in both regions, and (3) properties of potential recipient benthic communities

\begin{tabular}{|c|c|c|}
\hline & Nova Scotia & Southern England \\
\hline \multicolumn{3}{|c|}{ Codium fragile ssp. tomentosoides } \\
\hline Time of introduction & 1989 & 1939 \\
\hline Habitat & $\begin{array}{l}\text { Low intertidal and shallow } \\
\text { sublittoral zone (to } 13 \mathrm{~m} \text { ) }\end{array}$ & Low intertidal zone \\
\hline Size & Large plants $(60-70 \mathrm{~cm}$ max.) & Small plants $(25 \mathrm{~cm}$ max.) \\
\hline Abundance & $\begin{array}{l}\text { High abundance, large beds, } \\
\text { 'pests' }\end{array}$ & $\begin{array}{l}\text { Low abundance, small disjunct } \\
\text { populations }\end{array}$ \\
\hline Growing season & $\begin{array}{l}\text { Highest growth rates } \\
\text { July-October }\end{array}$ & $\begin{array}{l}\text { Highest growth rates } \\
\text { February-June }\end{array}$ \\
\hline Reproduction & $\begin{array}{l}\text { (1) Parthenogenesis, } \\
\text { (2) fertilization? } \\
\text { (3) thallus budding, } \\
\text { (4) fragmentation of adults }\end{array}$ & $\begin{array}{l}\text { (1) Parthenogenesis, } \\
\text { (2) fragmentation of adults? }\end{array}$ \\
\hline Substratum & $\begin{array}{l}\text { Attachment epiphytically } \\
\text { (coralline crusts, Porphyra, } \\
\text { Fucus) }\end{array}$ & $\begin{array}{l}\text { Attachment epilithically, } \\
\text { occasionally epiphytically on } \\
\text { coralline crusts }\end{array}$ \\
\hline \multicolumn{3}{|l|}{ Abintic conditions } \\
\hline Nutrients & Extremely oligotrophic & Oligotrophic to eutrophic \\
\hline Temperature & $\sim 0-19{ }^{\circ} \mathrm{C}(\min .-\max )$. & $-5-25^{\circ} \mathrm{C}(\min .-\max )$ \\
\hline Light & $\begin{array}{l}\text { Indirect evidence: kelp } \\
\text { communities from } 3-22+\mathrm{m}\end{array}$ & $\begin{array}{l}\text { Indirect evidence: kelp } \\
\text { communities from } 5-34 \mathrm{~m}\end{array}$ \\
\hline Wave exposure & $\begin{array}{l}\text { Exposed coast with protected } \\
\text { bays }\end{array}$ & $\begin{array}{l}\text { Exposed coast with protected } \\
\text { bays }\end{array}$ \\
\hline $\begin{array}{l}\text { Recipient sublittoral } \\
\text { communities }\end{array}$ & Realized by Codium & Not realized by Codium \\
\hline Structure & $\begin{array}{l}\text { Kelp forests; large brown algae } \\
\text { as primary producers, sea ur- } \\
\text { chins (Strongylocentrotus droe- } \\
\text { bachiensis) as main consumers }\end{array}$ & $\begin{array}{l}\text { Kelp forests; large brown algae } \\
\text { as primary producers, sea } \\
\text { urchins (Echinus esculentus) } \\
\text { as main consumers }\end{array}$ \\
\hline Floral diversity & Low & $\begin{array}{l}\text { High; more kelp species, } \\
\text { more fucoid species (canopy), } \\
\text { more red species (turf/epiphytes) }\end{array}$ \\
\hline $\begin{array}{l}\text { Intrageneric diversity } \\
\text { of Codium }\end{array}$ & C. fragile & $\begin{array}{l}\text { C. adhaerens, C. bursa, C. fragile, } \\
\text { C. tomentosum, C. vermilara }\end{array}$ \\
\hline $\begin{array}{l}\text { Intraspecific diversity } \\
\text { of Codium }\end{array}$ & 0 & Sspp. atlanticum, tomentosoides \\
\hline Species composition & Specific ' $A$ ' & Specific ${ }^{t} \mathrm{~B}^{r}$ \\
\hline
\end{tabular}


There are numerous examples of marine species which are consistent in their degree of abundance and dominance across various novel communities. Thus, the fucoid brown alga Sargassum muticum not only has become successfully established on many European coasts after its introduction from the Pacific Ocean (Rueness, 1989), but also is generally very abundant and often considered a nuisance species and thus a successful invader (Schories \& Albrecht, 1995, and references therein). In contrast, the green seaweed Codium fragile (Sur.) Hariot ssp. tomentosoides (van Goor) Silva, also from the Pacific Ocean, has been introduced successfully to European and New Zealand as well as Northwest Atlantic shores in the sense of permanent establishment and continual dispersal, but its abundance and community dominance varies significantly among these regions. Whereas $C$. fragile ssp. tomentosoides occurs regularly but in distinct and generally small populations around Europe, it reaches pest proportions on many shores of New England, USA, and Nova Scotia, Canada (Prince, 1987; Coleman, 1996; Garbary et al., 1997; Wallentinus, unpublished manuscript). In this paper I review the properties of Codium as a potentially successful invader on the one hand (Table 1), and of two contrasting recipient communities on the other (Table 2), and I suggest reasons for the differential success of Codium on the two sides of the Atlantic Ocean.

\section{CODIUM FRAGILE (SUR.) HARIOT SSP. TOMENTOSOIDES (VAN GOOR) SILVA}

The genus Codium belongs to the division Chlorophyta and comprises approximately 100 species (Silva, 1992). It is characterized by a siphonaceous organization of the thallus, i.e. its structural plan is based on multinucleate filaments rather than individual cells (Fig. $1 \mathrm{~B}, \mathrm{C}$ ). Although the coenocytic utricles on the surface of the thallus are similarly arranged among species, a broad range of macroscopic habits is found across the genus, including globose, crustose and branching erect forms (Silva, 1992). C. fragile is erect and dichotomously branched (Fig. $1 \mathrm{~A}$ ), and a cross-section of the thallus reveals the distinction between the strongly pigmented cortex of utricles and the translucent central medulla of extended utricle filaments (Fig. $1 \mathrm{~B}$ ). The only structures which are separated by septae are (1) utricle hairs and (2) gametangia. Among several subspecies of C. fragile, ssp. tomentosoides represents the one which has been most widely distributed and introduced to new environments, its origin most likely being Japan (Silva, 1955). C. fragile ssp. tomentosoides (in short Codium hereafter) exhibits a variety of attributes which have been proposed for potentially successful invaders (Lodge, 1993; Table 1). It grows to between 15 and $60 \mathrm{~cm}$ tall as an adult plant (Silva, 1955; Fralick and Mathieson, 1972; Benson et al., 1983) and may reach even $1 \mathrm{~m}$ length (Burrows, 1991). The life cycle is simple, with monoecious adults reproducing either sexually or parthenogenetically (Churchill \& Moeller, 1972; Fralick \& Mathieson, 1973; Hanisak, 1979; Prince, 1988). In both cases, the externally fertilized or the unfertilized female gamete gives rise to a juvenile tuft of dissociated filaments from which erect thalli grow under favourable conditions (Fletcher et al., 1989). Additionally, adult Codium may dissociate into filaments in the absence of shear forces (Ramus, 1972), and thallus fragments, as well as individual utricles, retain the potential for reattachment and regrowth into adult thalli (Fralick \& Mathieson, 1972; Ramus, 1972). Codium is considered perennial or pseudoperennial in that either the adult thallus or remains of the 


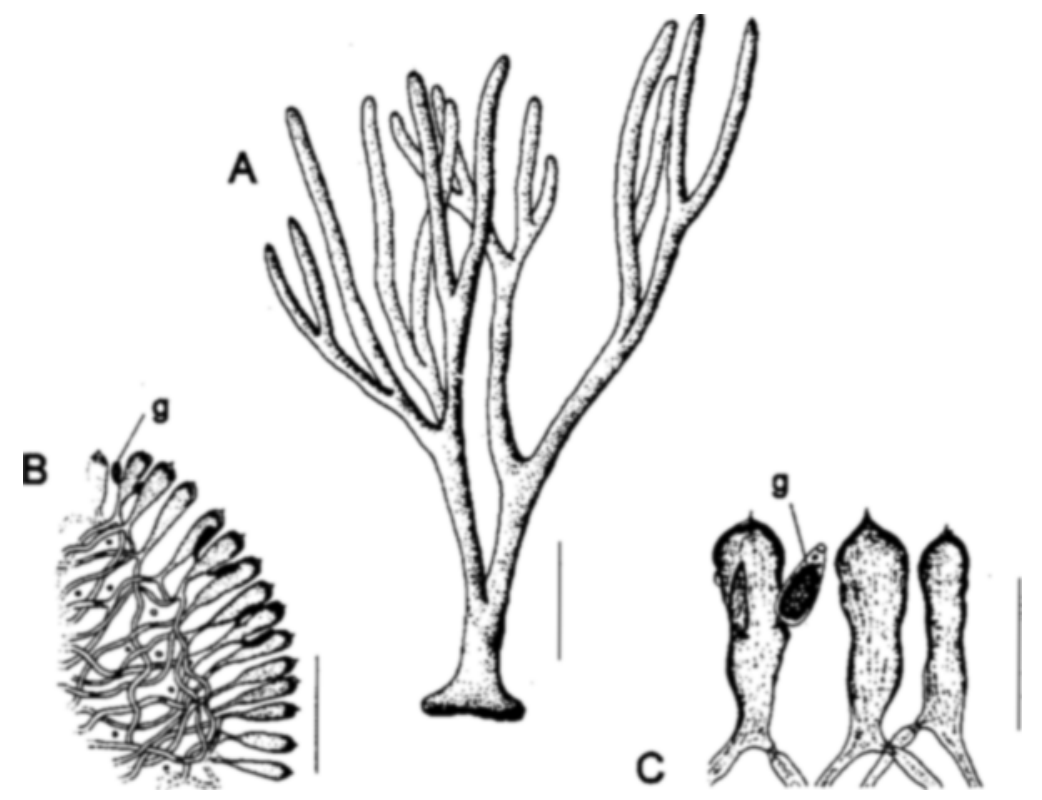

Fig. 1. Codium fragile ssp. tomentosoides; A: habit (scale bar $4 \mathrm{~cm}$ ), modified after Bold \& Wynne, 1978; B: cross-section of thallus branch (scale bar $1 \mathrm{~mm}$ ), modified after Bold \& Wynne, 1978; C: utricles with gametangia $(\mathrm{g})$ (scale bar $0.5 \mathrm{~mm}$ ), modified after Silva, 1955

holdfast persist over several years. Thus, the species exhibits a wide morphological and functional plasticity.

In a physiological sense, Codium is considered a warm temperate species with the optimum water temperature for growth and reproduction (formation and release of gametes) at $24{ }^{\circ} \mathrm{C}$ (Hanisak, 1979). However, growth and reproduction - both in laboratory cultures and in the field - are still possible at approximately $12^{\circ} \mathrm{C}$ (Churchill \& Moeller, 1972; Fralick \& Mathieson, 1973; Malinowski \& Ramus, 1973). Adults even survive winter temperatures as low as $-2{ }^{\circ} \mathrm{C}$ (Carlton \& Scanlon, 1985, and references therein).

Light requirements for growth of Codium are low in comparison with other fugitive green algae such as Enteromorpha sp. and Ulva sp. (Arnold \& Murray, 1980), and saturation photon irradiance generally varies between 60 and $90 \mu \mathrm{mol} \mathrm{m}^{-2} \mathrm{~s}^{-1}$ depending on the associated temperature and daylength (Hanisak, 1979). The thick, optically dense thallus of Codium prevents photoinhibition in full sunlight (Ramus et al., 1976; Arnold \& Murray, 1980).

Similarly, nutrient requirements are neither specific nor particularly high; Codium grows equally well with nitrate, nitrite, ammonium and urea as a nitrogen source (Hanisak, 1979) and it has the ability to store surplus nitrogen for growth during periods of limited external supplies (Hanisak, 1979; Hanisak \& Harlin, 1978). Furthermore, $\mathrm{N}_{2}$-fixation has been documented for cyanobacteria associated with Codium (Dromgoole et al., 1978); however, Gerard et al. (1990) suggest that hardly any of the fixed nitrogen is utilized by the seaweed. 
Overall, Codium is very persistent in the face of environmental fluctuations, and grows under a wide variety of irradiance and nutrient conditions. However, in contrast to truly opportunistic species (e.g. Ulva sp.) the trade-off in Codium for such flexibility lies in a comparatively lower growth rate (Ramus, 1978; Ramus \& Venable, 1987).

\section{INVASION HISTORY (WALLENTINUS, UNPUBLISHED MANUSCRIPT, AND REFERENCES THEREIN)}

Codium fragile ssp. tomentosoides was first reported in Europe in 1900 from Holland (Silva, 1955). From there it spread continually and rapidly around the continent: in 1920, it occurred in Limfjorden. Denmark (Silva, 1957) and since then has colonized the Skagerrak, Kattegat and Danish North Sea coast (Christensen et al., 1985). In 1930. Codium was discovered on Helgoland in Germany and since 1932 also occurs on artificial hard substrata off the island of Sylt (Kornmann \& Sahling, 1994; Schories et al., 1997). First reports of Codium from Bohuslän in Sweden date back to 1938 (Silva, 1957) and from Norway to 1952 (Silva, 1955). Wallentinus (unpublished manuscript) suggests that Codium was abundant after its first introduction in both Norway and Sweden, and has since been common but not dominant. Around the British Isles, Codium started spreading in 1939 when it was introduced to Devon in southern England (Silva, 1955). It moved northward to Ireland in 1950 (Silva, 1955), where it now occurs along the west and north coasts. Codium has reached southwest Scotland, but it is completely absent from the central Irish Sea (Burrows, 1991). On its way south, Codium was sighted in Atlantic France in 1946 (Silva, 1955), in the Mediterranean (from Banyuls to Marseille) in the 1950s (Gerbal et al., 1985; Riouall, 1985) and in northern Spain in the 1980s (PerezCirera et al., 1989). There are no records of Codium ever having spread to nuisance proportions in European waters, either immediately after its initial introduction or later.

In North America, the first record of Codium on the Atlantic coast was from Long Island Sound in 1957 (Carlton and Scanlon, 1985, and references therein). Codium spread north and south and its recent distribution ranges from North Carolina, USA (Searles et al., 1984) to Eastern Nova Scotia and Prince Edward Island (Gulf of St. Lawrence) in Canada (Bird et al., 1993; Garbary et al., 1997). In the Pacific Ocean, Codium was introduced to San Francisco Bay, USA, in the 1970s (Goff et al., 1992) and to Auckland, New Zealand, in 1973 (Dromgoole, 1975).

The original vector of transport to Europe is unknown for Codium; afterwards, epizoic transport on oysters within Europe, and movement of plants to North America attached to ships' hulls is considered most likely (Carlton \& Scanlon, 1985; Wallentinus, unpublished manuscript). Additionally, along the east coast of North America the dispersal of Codium probably has been facilitated by the use of plants as packing material in mariculture as well as by individuals attached to fishing nets (Carlton \& Scanlon, 1985).

\section{CODIUM FRAGILE SSP. TOMENTOSOIDES IN THE NORTHWEST VERSUS THE NORTHEAST ATLANTIC OCEAN (INCLUDING THE NORTH SEA)}

The variation in success of Codium between both sides of the Atlantic Ocean is expressed mainly as differential abundance in the intertidal and subtidal zones of coastal 
waters (Table 2). For a comparison of the recipient benthic communities of the Northwest versus the Northeast Atlantic Ocean, I have chosen Mahone Bay in Nova Scotia, eastern Canada, and the rocky coasts of southern England (Dorset and Devon). These locations appear reasonably representative of the biotic and abiotic conditions encountered on either side of the Atlantic Ocean as well as with respect to Codium abundance, and they will serve as sites for a field study of the community ecology of Codium in a transatlantic comparison. The problem of selecting a single area as representative for a coast which stretches across a wide latitudinal gradient (especially in the case of the Northwest Atlantic Ocean) is outweighed by the advantages of extensive knowledge about sublittoral community dynamics in Nova Scotia. The fact that the abundance of Codium is uniformly high all along the eastern North American coast (Carlton \& Scanlon, 1985; Bird et al., 1993) as well as over large temporal scales (between 10 and 40 years since its first introduction, loc sit) justifies the selection of a species community towards one end of the latitudinal gradient for the purpose of a transatlantic comparison.

In Nova Scotia, Codium grows attached in the low intertidal and shallow subtidal zones (Bird et al., 1993) to approximately $15 \mathrm{~m}$ water depth (Scheibling, personal communication; personal observation). The plants are large (max. $50-60 \mathrm{~cm}$ tall) and very abundant, locally forming dense beds, and often occur within kelp communities. Codium plants overwinter as adults and are thus perennial, although the growing season which is regulated by water temperature (Fralick \& Mathieson, 1973) extends only from approximately June to October. The modes of reproduction probably include (1) parthenogenesis of female gametes (Fralick \& Mathieson, 1973), (2) fertilization of female gametes as observed in populations from Maine (Prince, 1988), (3) budding of adult thalli and subsequent release of vegetative juveniles (several centimeters in length) in the summer (personal observation), and (4) winter fragmentation of adult thalli with potential reattachment of fragments (Fralick \& Mathieson, 1972). Depending on the availability of primary space, Codium either grows attached to rock (Bird et al., 1993) or epiphytically on other algae such as coralline crusts, Chondrus crispus or Fucus evanescens (personal observation).

In southern England, Codium occurs mainly in the low intertidal zone; only few records exist for subtidal specimens (Dyrynda \& Farnham, 1985). Plants seach up to $25 \mathrm{~cm}$ height and appear in disjunct occasional populations (R. Fletcher \& B. Farnham, personal communication). Although few large populations exist, local abundance is generally low. Codium populations from Bembridge (Isle of Wight) overwintered as small individuals $(5-15 \mathrm{~cm}$ ), with greatest growth rates during the winter months (Benson et al., 1983). The only reported mode of reproduction of Codium in the Northeast Atlantic Ocean and North Sea is through parthenogenesis of female gametes (Benson et al., 1983). Attachment is usually epilithic or epiphytic on coralline crusts, either exposed or within tide pools of lower shore elevations (W. Farnham \& R. Fletcher, personal communication).

Might the high abundance of Codium (particularly in the subtidal zone) on Northwest Atlantic coasts be explained by more favourable abiotic conditions in eastern Canada? This question must clearly be refuted: light and nutrient conditions are broadly similar in Nova Scotia and southern Britain (Slinn, 1966; Chapman, 1969; Chapman \& Craigie, 1977; Hatcher et al., 1977). Photon irradiance levels also are similar on 
both coasts as evidenced indirectly by similar depth distribution of kelp communities (Kain, 1971; Tremblay \& Chapman, 1980). Any expected discrepancies (higher average water temperatures, higher amplitude in variation of sea surface temperatures and comparatively eutrophic waters in southern England) should benefit the growth and survival of Codium, as temperature, in particular, is the primary factor regulating growth and reproduction in the species. Nevertheless, the abundance of Codium is limited in the Northeast Atlantic Ocean despite potentially more favourable abiotic conditions. Thus, the physico-chemical characteristics of the two regions do not explain the variation in success of Codium.

Alternatively, the structure or composition of the two benthic species communities targetted by biological invaders may elucidate why Codium is able to spread to nuisance proportions in eastern Canada but has never been reported in large abundance from southern England and remains restricted on northeast Atlantic shores. The invasibility of communities may be facilitated by a number of factors such as (1) disturbance, (2) low diversity of native species (congeneric with the invader and others), (3) absence of predators, and (4) early successional stage (Lodge, 1993). Here, I will examine theoretically the extent to which these factors may be applicable in a comparison between Nova Scotia and southern England, considering the immense variation in abundance of the successful invader Codium. However, the hypotheses put forward here need to be tested through comparative field experiments, especially since knowledge about the community ecology of subtidal habitats is very limited for the British south coast.

In both regions (Nova Scotia and southern England), kelp forests are the prevailing communities of the shailow sublittoral zone (to $20 \mathrm{~m}$ water depth) (Kain, 1971; Chapman, 1986). They have a similar community structure with large brown algae (Laminariales) as primary producers and urchins as major plant consumers (Kain \& Jones, 1967; Scheibling, 1984, 1986). However, the benthic floral species diversity in the Northeast Atlantic Ocean is approximately threefold that of the northwest Atlantic Ocean (South \& Tittley, 1986). This is reflected also in southern England compared to Nova Scotia in the greater amount of kelp and fucoid species in the shallow subtidal zone as potential competitors for Codium (South \& Tittley, 1986). Also, red algal species, which often grow epiphytically on Codium, are more numerous in Southern England than in Nova Scotia. Intrageneric (Codium) and intraspecific (C. fragile) diversity is high in the British Isles where there are five species of Codium and two subspecies of $C$. fragile (Silva, 1955), whereas in Nova Scotia the invasive C. fragile ssp. tomentosoides is the only representative of the genus.

As primary consumers of kelps, sea urchins (Strongylocentrotus droebachiensis) regulate kelp bed population dynamics in the Northwest Atlantic in periodic cycles of 10-12 years (Scheibling, 1986; Fig. 2). Thus, kelp communities shift between two major stages: (1) fully developed kelp beds with low or moderate urchin densities, and (2) 'barren grounds' affected by massive explosion of urchin populations and subsequent destructive grazing of all foliose macroalgae. Since urchins also have been shown to feed on Codium (Prince \& LeBlanc, 1992), the establishment (recruitment success) of this invasive species might be elevated during the transition period between the two states, which is characterized by the simultaneous absence of the main predator (S. droebachiensis) and potential kelp competitors. With regard to community invasibil- 


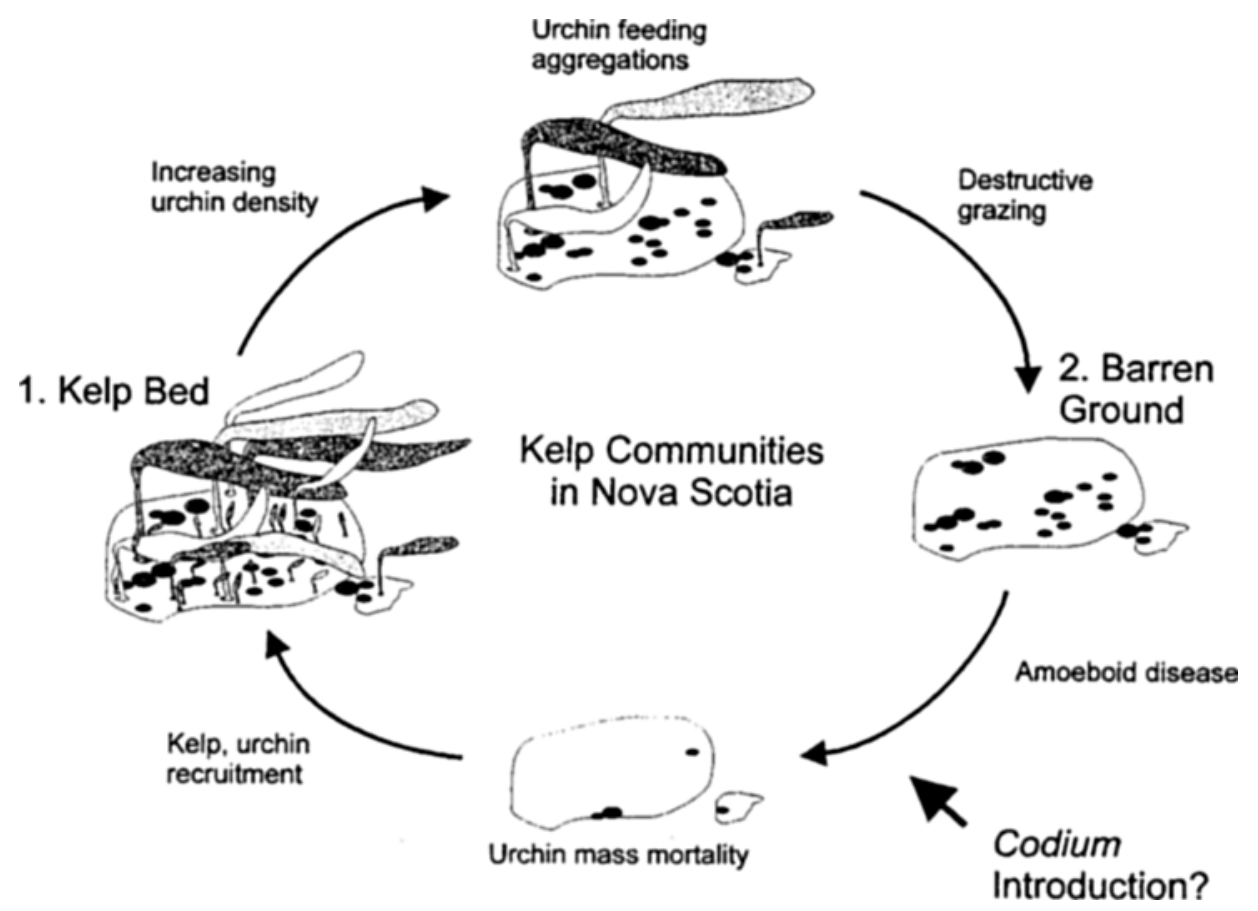

Fig. 2. Periodic cycle (10-12 years) of kelp communities in Nova Scotia (modified after Scheibling, unpublished). Healthy kelp community with grazing urchin population (stage 1). Increased urchin density and feeding aggregations graze destructively and gradually lead to barren grounds (stage 2). Insufficient food supply of sea urchins or an infectious amoeboid disease cause sea urchin mass mortality and allow new kelp-, and sea urchin recruitment. The simultaneous absence of potential kelp competitors and predators (sea urchins) may represent a facilitative time window for Codium establishment

ity, the barren state may be viewed as an early successional stage of kelp beds after severe biological disturbance, and may facilitate the establishment of invading species.

Additionally, the preceding recent establishment of the non-native bryozoan Membranipora membranacea in the Northwest Atlantic Ocean (Berman et al., 1992; Lambert et al., 1992) may have facilitated the success of Codium by affecting its competitive interactions with kelps. $M$. membranacea infests and rapidly overgrows large portions of the kelp blades, affecting growth and reproduction through elevated winter losses of kelp canopy. In contrast, Codium seems to be less fouled by the bryozoan (Scheibling, personal communication) and thus may be at a competitive advantage.

In contrast to the substantial insight into the community ecology of kelp beds in Nova Scotia (Scheibling, 1984, 1986, 1988; Scheibling and Stephenson, 1984), little is known about the processes and mechanisms determining community dynamics of kelp beds in southern England. Whether (1) a greater floral species diversity in southern England or (2) the constant abundance of sea urchin predators (Echinus esculentus) prevents the establishment of Codium in the subtidal zone remains to be investigated. Alternatively, the key to explaining differential abundance of Codium on two sides of 
the North Atlantic Ocean might not lie in structural community properties at all, but rather in particular biotic interactions of individual species with the invader. As an example, the absence of Laminaria hyperborea from the species community in Nova Scotia may be critical in comparison with southern England because of particular interactions of this kelp species with the invading Codium. Similarly, feeding habits and thus the impact of the primary predator on Codium populations may differ between sea urchin species from Nova Scotia and southern England. Despite structural similarities of subtidal kelp communities on both sides of the North Atlantic Ocean, the invasion success of Codium may be modified through biotic interactions at species level.

\section{CONCLUSION}

I suggest the following features of the non-indigenous C. fragile ssp. tomentosoides or the respective target communities to be responsible for the differences in abundance of Codium between the shallow subtidal zone of Nova Scotia and southern England:

1. The high floral species diversity in southern England compared to Nova Scotia may reflect strong competition pressure against Codium in various stages of its life cycle, preventing its establishment in the subtidal zone of Northeast Atlantic shores.

2. During the periodic cycle of kelp bed communities in Nova Scotia, barren grounds are created after severe biological disturbance and may represent a community stage which simultaneously lacks major competitors and predators of the invasive Codium. Thus, a time window is produced in which conditions are suitable for establishment of the introduced species. Such periodic kelp bed dynamics have not been reported for East Atlantic coastal communities and may very well be absent, not allowing the initialization of an invasive newcomer in the community.

3. The previous recent invasion of the bryozoan Membranipora membranacea may interfere with the competitive ability of kelps in Nova Scotia through the disruption of growth and reproduction of kelp species. Codium remains uninfested by the bryozoan and its success thus may be indirectly facilitated.

4. Although subtidal kelp bed communities are structurally similar on both sides of the North Atlantic Ocean, the distinct species composition in Nova Scotia versus southern England may lead to species-specific interactions between Codium and consumers (competitors), particular to each region.

Acknowledgements. I thank Karsten Reise for the invitation to an inspiring workshop about species introductions into the North Sea where this work was presented. Bob Fletcher and Bill Farnham engaged in various discussions with me on the state of Codium along the south coast of Britain. I also thank Tony Chapman, Anna Metaxas and Akira Peters as well as an anonymous reviewer for valuable comments on the manuscript. The research project on Codium was funded as a post-doctoral fellowship to myself by the German Research Council (DFG), and with grant A6497 of the Natural Sciences and Engineering Research Council of Canada to A. R. O. Chapman.

\section{LITERATURE CITED}

Arnold, K. E. \& Murray, S. N., 1980. Relationships between irradiance and photosynthesis for marine benthic green algae (Chlorophyta) of differing morphologies. - J. Exp. Mar. Biol. Ecol. 43, 183-192. 
Benson, E. E., Rutter, J. C. \& Cobb, A. H., 1983. Seasonal variation in frond morphology and chloroplast physiology of the intertidal alga Codium tragile (Suringar) Hariot. - New Phytol. 95 , 569-580.

Berman, J., Harris, L., Lambert, W., Buttrick, M. \& Dufresne, M., 1992. Recent invasions of the Gulf of Maine: three contrasting ecological histories. - Conserv. Biol. 6, 435-441.

Bird, C. J., Dadswell, M. J. \& Grund, D. W., 1993. First record of the potential nuisance alga Codium iragile ssp. tomentosoides (Chlorophyta, Caulerpales) in Atlantic Canada. - Proc. N.S. Inst. Sci. 40, 11-17.

Bold, H. C. \& Wynne, M., 1978. Introduction to the algae - structure and reproduction. - PrenticeHall, Englewood Cliffs, 706 pp.

Burrows, E. M., 1991. Seaweeds of the British Isles, vol. 2, Chlorophyta. - Natural History Museum, London, $222 \mathrm{pp}$.

Cariton, J. T., 1989. Man's role in changing the face of the ocean: biological invasions and implications for conservation of near-shore environments. - Conserv. Biol. 3, 265-273.

Carlton, J. T., 1996. Pattern, process, and prediction in marine invasion ecology - Biol. Conserv. 78, $97-106$.

Carlton, J. T. \& Geller, J. B., 1993. Ecological roulette: the global transport of nonindigenous marine organisms. - Science 261,78-82.

Carlton, J. T. \& Scanlon, J. A., 1985. Progression and dispersal of an introduced alga: Codium fragile ssp. tomentosoides (Chlorophyta) on the Atlantic coast of North America. - Bot. Mar. 28 , $155-165$.

Chapman, A. R. O., 1969. An experimental approach to the autecology of Desmarestia aculeata (L.) Lamour. PhD thesis, University of Liverpool, $153 \mathrm{pp}$.

Chapman, A. R. O., 1986. Population and community ecology of seaweeds. - Adv. Mar. Biol. 23, $1-161$.

Chapman, A. R. O. \& Craigie, J. S., 1977. Seasonal growth of Laminaria longicruris: relations with dissolved inorganic nutrients and internal reserves of nitrogen. - Mar. Biol. 40, 197--205.

Christensen, T., Koch, C. \& Thomsen, H. A., 1985. Distribution of algae in Danish salt and brackish waters. - Institut for Sporeplanter, Kobenhavns Universitet, 64 pp.

Churchill, A. C. \& Moeller, H. W. 1972. Seasonal patterns of reproduction in New York populations of Codium fragile (Sur.) Hariot subsp. tomentosoides (Van Goor) Silva. - J. Phycol. 8, 147-152.

Coleman, A. W., 1996. DNA analysis methods for recognizing species invasion: the example of Codium, and generally applicable methods for algae. - Hydrobiologia 326/327, 29-34 .

Dromgoole, F. I., 1975. Occurrence of Codium fragile subspecies tomentosoides in New Zealand waters. - N. Z. J. Mar. Freshw. Res. 9, 257-264.

Dromgoole, F. I., 1982. The buoyant properties of Codium. - Bot. Mar. 25, 391-397.

Dromgoole, F. I., Silvester, W. B. \& Hicks, B. J., 1978. Nitrogenase activity associated with Codium species from New Zealand marine habitats. - N. Z. J. Mar. Freshw. Res. 12, 17-22.

Dyrynda, P. E. J. \& Farnham, W. F., 1985. Benthic communities of a rapids system within the Fleet Lagoon, Dorset. - Progress in Underwater Sci 10,65-82.

Fletcher, R. L., Blunden, G., Smith, B. E., Rogers, D. J. \& Fish, B. C., 1989. Occurrence of a fouling. juvenile, stage of Codium fragile ssp. tomentosoides (Goor) Silva (Chlorophyceae, Codiales). J. Appl. Phycol. 1, 227-237.

Fralick, R. A. \& Mathieson, A. C., 1972. Winter fragmentation of Codium fragile (Suringar) Hariot ssp. tomentosoides (van Goor) Silva (Chlorophyceae, Siphonales) in New England. - Phycologia $11,67-70$.

Fralick, R. A. \& Mathieson, A. C., 1973. Ecological studies of Codium fragile in New England, USA. Mar. Biol. 19, 127-132.

Garbary, D. J., Vandermeulen, H. \& Kim, K. Y., 1997. Codium fragile ssp. tomentosoides (Chlorophytal invades the Gulf of St. Lawrence, Atlantic Canada. - Bot. Mar. 40, 537-540.

Gerard, V. A., Dunham, S. E. \& Rosenberg, G., 1990. Nitrogen-fixation by cyanobacteria associated with Codium fragile (Chlorophyta): environmental effects and transfer of fixed nitrogen. - Mar. Biol. 105, 1-8. 
Gerbal, M., Ben Maiz, N \& Boudouresque, C. F., 1985. Les peuplements à Sargassum muticum de l'Etang de Thau: donnees preliminaires sur la flore algale. - Sci. Fasc. 2, 241-254.

Goff, L. J., Liddle, L., Silva, P. C., Voytek, M. \& Coleman, A. W., 1992. Tracing species invasion in Codium, a siphonous green alga, using molecular tools. - Am. J. Bot. 79, 1279-1285.

Hanisak, M. D., 1979. Growth patterns of Codium fragile ssp. tomentosoides in response to temperature, irradiance, salinity, and nitrogen source. - Mar. Biol. 50, 319-332.

Hanisak, M. D. \& Harlin, M. M., 1978. Uptake of inorganic nitrogen by Codium fragile subsp. tomentosoides (Chlorophyta). - J. Phycol. 14, 450-454.

Hatcher, B. G., Chapman, A. R. O. \& Mann, K. H., 1977. An annual carbon budget for the kelp, Laminaria longicruris. - Mar. Biol. 44, 85-96.

Kain, J. M., 1971. Synopsis of biological data on Laminaria hyperborea. - FAO Fisheries Synopsis $87,34 \mathrm{pp}$.

Kain, J. M. \& Jones, N. S., 1967. Subtidal colonization following removal of Echinus. - Helgoländer. wiss. Meeresunters. 15, 460-466.

Kornmann, P. \& Sahling, P.-H., 1994. Meeresalgen von Helgoland: Zweite Ergänzung. - Helgoländer Meeresunters. 48, 365-406.

Lambert, W., Levin, P. \& Berman, J., 1992. Changes in the structure of a New England (USA) kelp bed: the effects of an introduced species? - Mar. Ecol. Prog. Ser. 88, 303-307.

Lodge, D. M., 1993. Biological invasions: lessons for ecology. - Trees 8, 133-137.

Malinowski, K. C. \& Ramus, J., 1973. Growth of the green alga Codium fragile in a Connecticut estuary. - J. Phycol. 9, 102-110.

Perez-Cirera, J. L., Cremades, J. \& Barbara, I., 1989. Systematic and synecologic comments about some new seaweed records for Galicia or for the Atlantic codsts of the Iberian Peninsula. Anal. Jard. Bot. Madrid 46, 35-45.

Prince, J. S., 1987. The invasion of Codium fragile ssp. tomentosoides into the Gulf of Maine. - Abstracts, North East Algal Symp. 26, 17.

Prince, J. S., 1988. Sexud reproduction in Codium fragile ssp. tomentosoides (Chlorophyceae) from the northeast coast of North America. - J. Phycol. 24, 112-114.

Prince, J. S. \& LeBlanc, W. G., 1992. Comparative feeding preference of Strongylocentrotus droebachiensis (Echinoidea) for the invasive seaweed Codium iragile ssp. tomentosoides (Chlorophyceae) and four other seaweeds. - Mar. Biol. 113, 159-163.

Ramus, J., 1972. Differentiation of the green alga Codium fragile. - Am. J. Bot. 59, 478-482.

Ramus, J., 1978. Seaweed anatomy and photosynthetic performance: the ecological significance of light guides, heterogeneous absorption and multiple scatter. - J. Phycol. 14, 352-362.

Ramus, J. \& Venable, M., 1987. Temporal ammonium patchiness and growth rate in Codium and Ulva (Ulvophyceae). - J. Phycol. 23, 518-523.

Ramus, J., Beale, S. I. \& Mauzerall, D., 1976. Correlation of changes in pigment content with photosynthetic capacity of seaweeds as a function of water depth. - Mar. Biol. 37, 231-238.

Riouall, R., 1985. Sur la présence dans l'Etang de Thau (Hérault-France) de Sphaerotrichia divaricata (C. Ag) Ky lin et Chorda fílum (L.) Stackhouse. - Bot. Már. 28, 83-86.

Rueness, J., 1989. Sargassum muticum and other introduced Japanese macroalgae: biological pollution of European coasts. - Mar. Poll. Bull. 20, 4, 173-176.

Scheibling, R. E., 1984. Echinoids, epizootics and ecological stability in the rocky subtidal off Nova Scotia, Canada. - Helgoländer Meeresunters. 37, 233-242.

Scheibling, R. E., 1986. Increased macroalgal abundance following mass mortalities of sea urchins (Strongylocentrotus droebachiesis) along the Atlantic coast of Nova Scotia. - Oecologia 68, $186-198$.

Scheibling, R. E., 1988. Microbial control of sea urchins: Achilles' heel or Pandora's box? - In: Echinoderm Biology. Ed. by R. D. Burke, P. V. Mladenov, P. Lambert \& R. L. Parsley. - Proc. 6th Int. Echinoderm Conf., 23.-28. 8. 1987. Brookfield. Balkema, Rotterdam, 745-754.

Scheibling, R. E. \& Stephenson, R. L., 1984. Mass mortality of Strongylocentrotus droebachiensis (Echinodermata:Echinoidea) off Nova Scotia, Canada. - Mar. Biol. 78, 153-164.

Schories, D. \& Albrecht, A., 1995. Sargassum muticum: der japanische Beerentang im deutschen Wattenmeer. - Natur Museum 125, 92-98. 
Schories, D., Albrecht, A. \& Lotze, H., 1997. Historical changes and inventory of macroalgae from Königshafen Bay in the northern Wadden Sea. - Helgoländer Meeresunters. 51, 321-341.

Searles, R. B., Hommersand, M. H. \& Amsler, C. D., 1984. The occurrence of Codium fragile subsp. tomentosoides and C. taylorii (Chlorophyta) in North Carolina. - Bot. Mar. 27, 185-187.

Silva, P. C., 1955. The dichotomous species of Codium in Britain. - J. Mar. Biol. Assoc. UK 34, $565-577$

Silva, P. C., 1957. Codium in Scandinavian waters. - Svensk Bot. Tidskr. 51, 117-134.

Silva, P. C., 1992. Geographic patterns of diversity in benthic marine algae. - Pac. Sci 46. 429-437.

Slinn, D. J., 1966. Chemical constituents in the sea off Port Erin during 1965. - Annu. Rep. Mar. Biol. Stat., Port Erin 79, 31-35.

South, G. R. \& Tittley, I., 1986. A checklist and distribution index of the benthic marine algae of the North Atlantic Ocean. - Memorial University of Newfoundland, St. Johns, $76 \mathrm{pp}$.

Tremblay, C. \& Chapman, A. R. O., 1980. The local occurrence of Agarum cibrosum in relation to the presence or absence of its competitors and predators. - Proc. N.S. Inst. Sci. 30, 165-170.

Trowbridge, C. D., 1995. Establishment of the green alga Codium fragile ssp. tomentosoides on New Zealand rocky shores: current distribution and invertebrate grazers. - J. Ecol 83, 949-965.

Vermeij, G. J., 1996. An agenda for invasion biology. - Biol. Conserv. 78, 3-9.

Wallentinus, I., unpubl manuscript. Introductions and transfers of plants. Inger Wallentinus, Department of Marine Botany, University of Göteborg, Carl Skottsberg gata 22, S-41319 Göteborg, Sweden. 